Territorial (In)Coherence: Labour and Special Economic Zones in Laos's Border Manufacturing James Alan Brown

School of Geography

Queen Mary University of London

james.brown@qmul.ac.uk 


\begin{abstract}
This article engages literature on special economic zones and territory in global development. I suggest a focus on labour's spatial class composition as constitutive of territorial coherence provides insights into how the Savan-Seno Special Economic Zone in Lao PDR operates as an economic border territory bridging Laos to the regional and global economies. The distanciated global connections which special economic zones aim to create are predicated on zones gaining internal coherence for capital accumulation. I suggest zones' internal coherence depends on zone firms reworking the local class composition of labour, itself constituted by workers' spatial practices. In the Savan-Seno zone this occurred through immobilizing a mobile labour force and taking advantage of its continuing embeddedness within a subsistence rice-producing village economy. The argument aims to illustrate how zones producing for global markets act as territories of complex spatiality which span and connect multiple spaces of production and workers' social reproduction.
\end{abstract}

Key words: Laos; labour; special economic zone; territorial coherence; borders

\title{
Introduction
}

The Savan-Seno Special Economic Zone (SASEZ) is located in southern Laos on the border with Thailand. The zone is part of a cluster of light manufacturing enterprises which foreign investors have established in increasing numbers since the late 2000s in the town of Savannakhet. The zone represents a flagship industrial development project of the Lao PDR government and is strategically located along the Asian Development Bank (ADB)-sponsored East West Economic Corridor (EWEC), a transport infrastructure project traversing continental Southeast Asia. The policy of "turning land into capital" (Lestrelin et al 2012) is part of the Lao government's drive for foreign investment, through which it hopes to spur economic development. Foreign investments in Laos have thus notably concentrated in the natural resources and agriculture sectors (Baird et al 2015; Baird 2011). Special economic zones are also turning land into capital by providing territory for foreign-invested industrialization. Manufacturing capital in Laos therefore represents an increasingly pertinent strand of investment requiring critical investigation.

The SASEZ's border location and the parcelling of Lao space to attract industrial capital indicate the important role of territory. The territorial bounding of space and political economic differentiation between sub-national and national territories can, in my view, offer a productive angle for analysis (Mezzadra and Neilson 2013). I aim to reaffirm territory's salience and suggest an analytical framework for understanding the territorial constitution and effects of special economic zones. The argument builds on literature describing zones as "experimental" territories of global connection (Doucette and Lee 2015; Ong 2006) by identifying the granular constitution of zones as economic territory; specifically how they are constituted by the spatialized practices and relations of labour. Zones gain relevance through the territorial differentiation which bounding creates. This manoeuvre 
of demarcation has however a complex spatiality that goes beyond creating a "node" that articulates "a tighter global economic system" (Bach 2011, 115). The reworking of territory involves composing new social relations within the zone, across the zone and the surrounding national territory, and between the territory of the zone and its beyond, other territories and networks of the global economy. The functioning of zones is determined by bringing these territorialized relations into provisional, working alignment. Tracing the social relations which constitute zones across these interwoven spatial spheres helps us to understand how different actors benefit from zones, what contradictions and fissures problematize them, and why certain strategies are enacted and outcomes generated.

To substantiate these claims I develop a notion of territorial coherence, suggested by Swyngedouw (1992), but reconceptualizing this through the autonomist Marxist notion of class composition (Cleaver 1992) and remaining sensitive to the constitutive role of borders described by Mezzadra and Neilson (2013). The use of autonomist Marxism by recent work in economic geography (Cumbers et al 2010) is extended by spatializing class composition; fixity and mobility are interpreted as constitutive of labour's composition. This approach has several benefits. It overcomes the limits of approaches to territorial change which under-specify the role of labour, its social reproduction and agency. It integrates workers' spatial practices into the weft of class composition, making the latter a fuller analytical tool. The notion of a spatialized class composition as constitutive of territorial coherence thus provides a bridge between everyday practices and wider processes of spatial change, bringing a broader set of empirical phenomena into a single frame. I propose that the SASEZ represents an attempt to build a new form of territorial coherence between a parcel of Lao territory and the established, largely Thailand-based, production networks of multinational firms investing in the zone. This form of territorial coherence can be understood as relationally connecting distant locations through "bordering technologies" (Mezzadra and Neilson 2013, 211) as well as connecting contiguous territories. The internal coherence within the zone - and so the coherence between Laos and Thailand - was dependent on attaining territorial coherence between the zone and its Lao hinterland, meaning immobilizing a mobile labour force and taking advantage of its continuing embeddedness within a subsistence rice-producing village economy. I argue that an existing spatialized class composition of an agriculturally-based yet mobile and migrant class in the border area was a barrier which capital had to accommodate with in order to establish a new spatial organization of accumulation. Special economic zones, it is suggested, can then be read as a constructed and contested form of coherence which brings heterogeneous elements - capital, land, labour, and regulation - into an always provisional configuration where the distribution of generated value is determined in important ways by spatialized forms of struggle. 
The article proceeds in five sections. I first engage literature on the role of special economic zones in the global economy. I then advance a notion of territorial coherence, inspired by Sywngedouw (1992), extended with the concept of class composition (Cleaver 1992) and informed by Mezzadra and Neilson's (2013) emphasis on the generative powers of borders. I propose that the notion of territorial coherence can be applied to special economic zones and regionalization. Third, I outline the Lao government's special economic zone policy within its broader territorialization strategy and the Greater Mekong Subregion (GMS) regionalization programme. Fourth, the article focuses on the case of the implementation of the Savan-Seno Special Economic Zone. Fifth, I analyze the Savannakhet class composition and capital's responses to it to illustrate the theory outlined.

\section{Special Economic Zones}

Special economic zones (SEZ) have proliferated for half a century. The prominent position which zones have in structuring global production arguably make them "paradigmatic" for understanding the contemporary global situation (Mezzadra and Neilson 2013, 209). Special economic zones are characterized by governments offering to investors a package of tax exemptions and holidays, tariff waivers, productive infrastructure, transport infrastructure, and a low cost of labour (Neveling 2015). SEZs thus hold mobile capital in place by freeing it from the usual fetters of state regulation. Neveling (2015) notes that SEZs have become a favoured development strategy for countries with few other industrialization options in the globalized era. SEZs have become notorious for two main reasons; exploitative labour conditions (e.g. Gunawardana 2016), and land dispossession (e.g. Levien 2012). SEZs have thus become a contentious - but widespread - model of accumulation, typically linked to global circuits of production and trade.

Aihwa Ong (2006) offers an important starting point for understanding zones' geographies of connection. She highlights zones as spatial innovations which form connections across the topography of uneven development. Zones function as spaces of exception which facilitate transnational investments and also serve as channels through which to engage and ease geopolitical tensions. Ong's notion of zones as mobile neoliberal "zoning technologies" however tends to be "insufficiently grounded in particular actors or stakeholders" (Arnold 2012, 744). There is little sense, for instance, of how workers may have an active role in determining zone realities, or zones' "structural continuity and dynamic interrelations" with the "informal" or "non-accumulative" activities occurring outside them (Cross 2010, 358). Rather, zones are better viewed as simultaneously apart from yet "entangled" in a wider political economy (Appel 2012). It is appropriate then to follow Doucette and Lee $(2015,55)$ in considering zones as forms of "experimental territoriality", invoking the spatially innovative character identified by Ong, but involving "a diverse and volatile mix of actors, interests and 
infrastructures". Zones can thus depend on distinct legal norms and exceptions as well as "formal and informal practices that cut across specific territorial boundaries whose contexts should not be elided" (Doucette and Lee 2015, 55). Drawing on Raffestin (2012), Doucette and Lee focus on "territoriality", the condition or status of territory. For Raffestin $(2012,121)$ territoriality is a construct of material and immaterial relations as well as representations of those relations, a useful analytical orientation for the focus on labour relations developed here. Raffestin's work is also valuable for the proposal that territories are produced by means of other territories. Transformations of territoriality are wrought through "the reshuffling or abandonment of certain (territorial) constructs to permit the insertion of other activities linked to new or transformed relations" (130). The perspective of territorial coherence here highlights zones' always provisional constitution as forms of territory that simultaneously create new alignments between bounded political units, by engaging new relations of production and social reproduction both inside and outside of zones; that is how zones gain form through their interaction with other territories and the relational practices which traverse and knit them together.

\section{Territorial Coherence and Spatial Class Composition}

The value of territory for understanding global economic change persists in that contemporary economic processes can be seen as actively constructing, combining and utilizing the differences between heterogeneous bounded spaces (Mezzadra and Neilson 2013). I accept here a definition of territory as a demarcated, regulated space, while noting that "Delimitation, contiguity and coherence" that mark territory "have to be constantly reproduced" (Painter 2010, 1105). While some scholars have privileged the relational, networked nature of politics and economics which transcend territorial jurisdictions (e.g. Amin 2002), others have sounded a more structured approach to relationality. They acknowledge the validity of relational thinking's insights while stressing "the confined, connected, inertial, and always context-specific nature of existence and emergence" (Jones 2009, 489) and complementarity of "closed, bounded and homogenous" and "open, permeable and heterogeneous" conceptualizations of space (Hudson 2007, 1151). For Painter $(2010,1093)$ territory and network thinking are thus compatible approaches, positing territory "not as an irreducible foundation of state power" but rather as an "effect" of networked "socio-technical" practices. Territory is therefore here understood as gaining realization through the social relations and spatial practices of key actors. Before I turn to a discussion of Laos, I flesh out how zones can be conceptualized as relational territories

In my view there is potential to enrich these discussions by advancing a more stridently political economic frame. This aim accords with Cox's $(2013,55)$ call to specify "the structure of relations that provides the necessary condition" for territorialization. That is, to go beyond networked social 
relations in the abstract to the central role of capitalist social relations in territory's formation. To do so I reformulate tenets of geographical-historical materialism. Harvey (2006) argues that a specific spatial configuration suitable for capital accumulation in one period may over time become a barrier to accumulation as the demands of valorization shift. Swyngedouw (1992) develops this theme into a suggestive argument. Swyngedouw conceptualizes territorial organization in a dual manner as both force and relation of production. Territorial organization comprises: natural resources; material and social infrastructure; the institutional and regulatory forms necessary for the territorial configuration's cohesion; and the characteristics of individual capital units (418). Swyngedouw appears to suggest that specific forms of territorial organization have a greater or lesser degree of territorial coherence for capital accumulation: "Territorial coherence...refers to a specific combination of the form of territorial regulation with a concrete form of the valorization process which generates a relatively stable pattern of territorial development" (419). Territorial organization constantly develops through reconfiguration of complex technical and spatial divisions of labour as particular forms of territorial organization become barriers to further growth (428). Territorial reorganization thus also implies reconfiguring the relations of production with "continuous struggle over spatial organization, not only between capitalists, but also between reproduction and production space" (425; cf. Raffestin 2012). The struggle over reproduction and production space implies to me that, a form of territorial organization can be coherent for social reproduction over capitalist production. Evident here are similarities with Berndt and Boeckler's (2011) notion of "b/ordering", in which attempts to order economic phenomena with controllable frames, such as borders, are always complicated by that which exceeds or overflows them. Territorial organization of production and circulation is potentially made incoherent for accumulation as the configuration must contend with the concrete forms of social reproduction which both make valorization possible and also contradict it. The inherited territorial unity of the forces and relations of production may thus act as an important barrier to attempts at territorial reorganization.

Borders as Mezzadra and Neilson (2013) point out are crucial for the reshuffling of territorial constructs as their malleability, selective opening and marking of legal exception allow new connections to be made. They can "fold" the distance between spaces in different territories, acting "as parameters from which efficiencies can be produced" (206). Indicated here are the productive tensions between topographical and topological elements within a relationally constituted notion of territorial coherence (Doucette and Lee 2015, 55; cf. Allen 2011). While territorial coherence can be seen in a topographical sense of, for instance, aligning territorialized regulations, implied also is the forging of new capital-labour relations that stretch across space to create "a strange form of proximityin-distance" (Mezzadra and Neilson 2013, 212). Territorial reorganizations in search of new forms of 
coherence can be therefore highly selective and uneven in their connections, the perspective here echoing key themes of work which identifies "dis/articulations" in global production (Bair and Werner 2011).

Territorial coherence as a relation of production is underspecified in Swyngedouw's analysis and I propose integrating insights from autonomist Marxism to account for the role of labour. The key point that autonomist Marxist approaches make is that the practices and struggles of labour, which may take place within or without formal organizations such as trade unions, are the key drivers of capitalist development rather than law-like structural features (Cleaver 1992). Class composition is the central concept in autonomist thought. Class composition represents an "inversion" of Marx's emphasis on the composition of capital in determining the trajectory of capitalist development (Cleaver 1992) and refers to the power and organization of the working class in relation to capital in a given configuration of production. The composition of class in production is given by the social and technical division of labour in a specific organization of constant and variable capital (Cleaver 1992; Dyer-Witheford 2004). It confers power on the working class and enables resistance. Composition is also formed through the cultural milieu, organizational forms and political direction of a specific context (Dyer-Witheford 2004). The notion is made dynamic through its extension into the concepts of class decomposition and class recomposition. In class decomposition firms reorganize the division of labour and change the composition of capital - by for example investing in labour-shedding technology - to undermine working class power. In class recomposition workers find ways to recompose their power and organization in the new configuration (Cleaver 1992). Radical geographers have integrated autonomist insights into analyses of global production networks and post-industrial restructuring (Cumbers et al 2010; Cumbers et al 2008). The aim has largely been to reaffirm the determinative power of class struggle and workers as active agents, an endeavour part of a broader trend in economic geography to refine the concept of labour's agency (Coe and Jordhus-Lier 2010). As such the use of autonomist Marxism has tended toward a non-spatial concept of class composition within an otherwise spatial analysis. Cumbers et al (2010), following Cleaver, read the moment of class recomposition in terms of "self-valorization" projects which "construct alternative spaces" (59) away from the domineering grasp of capital. The issue here is that space only appears to enter into the effects of the composition rather than the constitution of the composition itself; the composition produces space rather than space being integral to the composition. While the spatially productive aspect of class composition should be a necessary component of analysis, I propose that if geographers are to wield the concept for their own analytical ends the social and the spatial can be combined more rigorously. ${ }^{1}$ 
One possible way to integrate space into class composition is to establish worker practices of mobility and fixity as a potentially important component. The extent to which workers are able to command space for their own ends constitutes an important source of power. Workers can possess a degree of "mobility power" where they are able to leverage ability to move from a firm into increased wages or benefits as firms attempt to retain them (Smith 2006). Restricting workers' mobility can thus become a key strategy of capital to decompose their power (Pun and Smith 2007). Migration similarly offers a source of potency for workers, notwithstanding that migrant workers are often subjected to rights abuses. Mobility emerges as a terrain of struggle on which workers can strategize both occupationally and transnationally to reproduce their lives on more advantageous terms (Alberti 2014).

The meaning of fixity with regard to labour is perhaps less obvious but appears to me as of equal importance to mobility. My approach to the labour-centred concept of fixity incorporates material aspects but emphasizes social reproduction and the strong ties which workers have to particular places, the spatially fixed matrices of family, community, and social institutions from which workers originate and consistently reproduce through work, social and cultural practices (Kelly 2009). Fixity is thus defined as establishing and reproducing the dense social relations, as well as material resources and activities which sustain these relations, in the places in which workers live and reproduce. The concept of fixity resonates with notions of "embeddedness" (Dunn 2004) but diverges in viewing workers' strong relations to places less as a resource for trade union organization (Carmichael and Herod 2012) - although they may function as this - and more as the socially reproductive practices which maintain those places. These may include "care strategies" (Pearson and Kusakabe 2012), controlling material resources such as land (Manivong et al 2014), creating housing infrastructure (Mercer 2017) and, perhaps paradoxically, labour migration and remittances (Kelly 2009). Following Ollman (2003) fixity and mobility are in a dialectical relation which is contradictory and interpenetrating. Interpenetration describes the quality of a phenomenon appearing differently depending on an observer's position within social relations. For example the fixity expressed in a migrant leaving a job to return home to care for family would be perceived as the worker's inherent mobility from the employer's side. Workers' fixity from the perspective of capital would be the need to fix them in place in production (Smith 2006). From the perspective of the state, fixity is holding enough workers in place to meet national labour market requirements, either by retaining enough national citizen workers (Agbiboa 2012) or attracting and retaining foreign workers (Arnold and Pickles 2011). That the variously positioned actors in capitalism have such priorities in this regard, and strategies to achieve those priorities, underscores fixity and mobility's importance to struggles over class composition. 
A spatially constituted class composition, grounded in worker practices of fixity and mobility, can now be interpreted as a central component of territorial coherence. For example, facilitating worker migration to a special economic zone and fixing them in place in a "dormitory labour regime" (Pun and Smith 2007) would be key for establishing the territorial coherence of relations of production for capital accumulation within the zone and between the zone and the migrant sending area; first folding these disparate spaces together in order to then construct the territory as a portal of connection with distant production locations or owners of capital. Alternatively, local workers still ensconced in natal households may provide hidden social reproduction-related subsidies to firms and so establish a different form of territorial coherence (Kelly 2013). The import of migrant workers to undercut wages and conditions (Ince et al 2015) can be interpreted as an attempt on the part of capital to recompose a coherence that is favourable to social reproduction, as can struggles over land grabbing and enforced proletarianization (Baird 2011). In this way it starts to become clear how an inherited spatialized class composition might become a barrier which capital must overcome to establish a territorial organization coherent for accumulation. I suggest that when we consider SEZs we should consider how through regulation, material infrastructure and struggle over class composition territorial coherence is achieved within the zone. This to a large extent is determined by the territorial coherence achieved through a spatialized class composition across the spheres of production and social reproduction space in the (national) territory/ies outside the zone. Achieving territorial coherence for capital accumulation in these areas is then constitutive of territorial coherence between national territories, and spaces within them. As much as zones attempt to create "proximity-in-distance" (Mezzadra and Neilson 2013, 212) that serves the spatial strategies of globalising capital, they are simultaneously "entangled" with the local social relations of the places they inhabit with "considerable work required to produce the effect of the separation itself" (Appel 2012, 443, original emphasis). The distanciated relationality of zones emerges through a contested, negotiated process that compels zone companies to engage with both proximate and distant forms of worker mobility and fixity. Questions of inherited barriers to new territorial organization are pertinent in processes of regionalization, with actors arguably primarily interested in securing new forms of territorial coherence between national jurisdictions (Faludi 2013). The case of the Savan-Seno SEZ in southern Laos will illustrate these points, the national context of which is a broader process of state territorialization and regionalization.

\section{Lao Development Policy: Special Economic Zones and Regionalization}

Laos's SEZ policy is part of a broader spatial development strategy of "turning land into capital", enclosing land and resources to attract, mainly, foreign capital (Lestrelin et al 2012). The broad aims of SEZs are "to contribute to a rapid socio-economic development" and to integrate the "Lao economy 
into the regional and international economies" (GoL 2012, i). The fact that many SEZs are placed on borders means they offer a privileged lens for understanding regional integration in Laos (Laungaramsri 2014; Tan 2012). By the time of the author's fieldwork in 2013-2014 the government had legally established ten special economic zones but only three had begun operation (GoL 2016). The SASEZ was the only one of these three oriented primarily towards industrial development, with the others operating models of casino-based tourism (Nyiri 2012; Tan 2012).

Regional integration at the time of fieldwork in 2013-2014 was taking place through the Greater Mekong Subregion (GMS) project, ${ }^{2}$ a cooperation and integration programme between the five countries of mainland Southeast Asia as well as two southern provinces of China, sponsored and promoted by the Asian Development Bank (Glassman 2010). The GMS Programme hinges on a system of "economic corridors" - largely constituted by transport infrastructure - which traverse mainland Southeast Asia from north to south and east to west, with Laos transected by both axes (Fau et al 2014). Laos hopes to implant its own industrial structure, especially SEZs, within this transport network (ADB 2016). This development strategy should also be interpreted in light of Thailand's GMS participation and border development strategies. Glassman (2007) has commented that Thailand has previously engaged in a "low-road" spatial fix where low-cost export platforms are sought for investors at border sites in order to escape crises of profitability, for example at the industrial zone in Mae Sot to access cheap Burmese labour (Arnold and Pickles 2011). Notably, the SASEZ lies at the opposite Thai end of the EWEC to Mae Sot and can be viewed as part of a new round of reorganization of the Thailand-centred regional production structure. Transport infrastructure has facilitated integration by allowing the extension of Thai-based production networks into Laos (Oraboune 2011). Many of these production networks are those of multinational firms originating in developed countries. Laos's integration into global circuits of capital is thus mediated through Thai territory.

\section{The Savan-Seno Special Economic Zone}

The SASEZ, and the town of Savannakhet, have become a locus of regional industrial integration in recent years. The town of Savannakhet (officially Kaysone Phomvihane district) is situated on the Thai border in the province of the same name (Savannakhet) in southern Laos, at a key articulating point along the EWEC (Nolintha 2011). The smaller town of Seno lies some $30 \mathrm{~km}$ to the northeast. The SASEZ was attracting FDI in the wider context of increasing provincial integration with regional foreign capital in the past decade. In the period 1992-2005 provincial statistics record cumulative foreign investment of US\$ 26.7 million (SPA 2014). ${ }^{3}$ In the period 2006-(mid)2014 registered foreign investments ran at US\$553 million. China was the largest source of FDI over the period with US\$145.5 million, followed by Thailand and Vietnam. Foreign investment in the industrial sector totalled 
US\$105.8 million between 1992-2014, with the vast majority, US\$88.6 million, coming in the period 2007-2014, and largely attributable to the development of the zone.

The town had a small but developing industrial profile when the SASEZ became operational in 2011. Several foreign-invested factories, including a garments factory, a sock factory and a motorcycle assembly factory were established in the 1990 s or early 2000s. Bua Pagop Manufacturing ${ }^{4}$ (BPM), a joint venture between Japanese, Lao and Thai investors opened in 2009, and manufactures camera components for a Japanese multinational firm which has its main regional production base in Thailand. The motivations of BPM for establishing production in Savannakhet were indicative of export-oriented foreign investors' attitudes: cheap labour and a positioning at a node in regional transport infrastructure (factory manager 10 June 2014). Two factories, including BPM, studied during fieldwork preceded the opening of the zone and lay outside it. They shared key features (labour-intensive, export-oriented) with zone factories however, providing the pre-history of the zone's territorial coherence and also setting the labour market context which shaped the SASEZ's reterritorialization.

SASEZ was formally established by Prime Minister's decree in 2003, although development was slow and the zone was officially opened for business in November 2011 (Vientiane Times 2011). The SavanSeno Special Economic Zone Authority (SEZA) is the state organization responsible for zone administration. SEZA is an example of a rescaling of the Lao state aimed at facilitating swift entry of foreign capital through providing a "one-stop" service for registration and permits (SEZA official 20 December 2013). Investors have been attracted to the zone with incentives such as 75 year land leases, profit tax breaks, tariff waivers on goods used in the production process, and repatriation of business operations profits (GoL 2003). The zone is now divided into four sub-zones each with a different focus: Zone A commerce; Zone B logistics and production; Zone C production; and Zone D residential. Zone C was the most well-advanced of the zones at the time of fieldwork in 2013-2014. Factories in Zone C, and one in Zone $\mathrm{B}$, were the primary object of the fieldwork.

The first company to start production was a Dutch manufacturer of aircraft cabin components in 2011. Opening of new factories was then limited until 2013-2014 when a clutch of companies started operations. Factories mainly manufactured components - including camera components and car seats - rather than finished goods. Japanese and European firms predominated amongst zone manufacturers. Factories moved to the zone to take advantage of cheap labour and production costs as well as proximity to Thailand, with connections facilitated by the EWEC infrastructure. As one zone factory manager put it, "The target is to make profits...We have factories in Thailand, Philippines, in India, Vietnam, in China. All those factories are high cost because of the labour costs, and we saw that the Lao government has good policies to attract" (27 February 2014). Of the seven factories studied, 
five had existing production networks in Thailand, either in the Bangkok Metropolitan Region or eastern seaboard, and had moved part of their production to Laos. One more was a new joint venture between Thai, Japanese and Lao capital with strong links to another non-zone Savannakhet factory (BPM) and its Thai-based parent company. A manager from the Malaysian private zone developer company explained succinctly: "They already have factories in Thailand, so now they have to move out from Thailand, so Laos is the first choice... we are nearest to Thailand" (13 January 2014).

There was scant evidence that the zone was operating as anything other than an export platform. This was despite the government's awareness that forward and backward linkages were needed for the zone to have a broader effect on Laos's industrial development (SEZA official 20 December 2013). Firms had few relations with local suppliers and utilized tariff waivers to import components and materials from Thailand for assembly and further processing. The components which companies manufactured were then either re-exported to Thailand for assembly into final products in the companies' main regional factories in Thailand or exported to final markets through Thai transport networks, and in one case Vietnam (factory managers 10 January 2014: 27 February 2014; 16 May 2014). In this sense the constructed territorial coherence was one of simultaneous excision and blurring, overlapping a portion of Lao territory with Thailand in order to fold together distant production locations. Savannakhet's key strategic position on the Lao-Thai border and along a regional economic corridor thus allowed foreign investors to take advantage of low labour costs in Laos while at the same time moving products swiftly to further processing. This recalls Berndt and Boeckler's (2011) notion that mobile commodities and people cause borders themselves to be mobile, an elastic stretching of the Lao-Thai border into the space of the zone. Savannakhet border manufacturing thus represents a territorial reorganization of the forces of production which allowed companies to cut costs by accessing an expanded spatial arena of capital circulation. This created a new form of territorial coherence between Laos and Thailand. The zone's regulatory exception was an important crux of reorganization. Capital and the Lao state created a highly specific and exclusionary channel of economic coherence between the production networks on Thai territory and the Lao zone by simultaneously eliding the border while invoking the developmental difference it demarcates (cf. Arnold and Pickles 2011). A technical division of production dependent on distanciated, developmentally uneven locations, and so in turn on intensified mobility of inputs and outputs, was made possible through this blurring of the Lao-Thai border and the zone's borders. The forces of production - the zone's infrastructure and factories - and the regulatory sleight of hand both dissolving and accentuating the border - only represented half of the story. To attain territorial coherence the local class composition had to be reworked to fully enable the bordering effect. 


\section{Class Composition and SASEZ's Territorial Coherence}

Mobility

Zone firms' operations were hindered by difficulties in recruiting and retaining workers, stemming from workers' spatial practices of fixity and mobility; a class composition based on the axis of agriculture and migration to Thailand. Within this composition there were three important types of mobility: international migration, labour market mobility, and mobility between agriculture and industry, the latter indicating a relation with fixity. Savannakhet province is the most populous Lao province with 953,511 inhabitants recorded in the 2013 census, and Kaysone Phomvihane district's population numbering 128,182 (GoL 2014). This would seemingly provide a large enough pool of workers for new factories. However, the provincial labour market was in fact tight due to significant migration to Thailand, the first important form of mobility. A factory manager described how the company had surveyed the labour situation when looking to invest in Savannakhet in the late 2000s and received information that many people were looking for employment. "That's why we chose [to move to Savannakhet]...but it's not true!" (10 June 2014). Provincial statistics record 35,607 migrants from Savannakhet province as working abroad in $2013,53 \%$ of whom were women (SPA 2013). Only 88 workers in 2013 went through official channels of labour recruitment with a porous border facilitating undocumented migration. The official total figure may however be an underestimation. Estimates from a local labour recruitment company put the provincial number at 75,000 in 2014 (factory manager 10 June 2014). What was clear was that migration was affecting local recruitment. Migrants from Savannakhet come mainly from the more densely populated western districts of the province which lie in close proximity to the Thai border (SPA 2013). Migrants cited a lack of job opportunities and higher wages in Thailand as key reasons for migrating (30 May 2014; 8 June 2014). Workers who had experienced migration all reported that they remitted money and this played an important role in reproducing home villages.

A higher proportion of migrants was female (SPA 2013). Higher female rates have been attributed to less access to employment within local labour markets and the increased cultural acceptability of migration generated by space-compressing infrastructure (Khumya and Kusakabe 2015). The gender balance of migration was especially relevant in that factories engaged in a social construction (Caraway 2005) of the labour force which hired young women due to their perceived aptitude for detailed tasks and docility (factory managers 13 January 2014; 16 May 2014). Factories thus appeared to be chasing a segment of the labour market which was more likely to migrate and so apparently this had the unintended consequence of inhibiting recruitment. Migration to Thailand constituted an existing form of territorial coherence between Laos and Thailand. Lao migrants were incorporated 
into distant Thai capitalist enterprises, stretching class relations transnationally. Thai and Lao territories were linked together via mobile class relations, these generated by the uneven levels of development demarcated by the border. Lao migrants integrated into the wider economy of the region at their own behest, an action which would complicate border manufacturing. The tight labour market created the conditions for a second form of labour mobility to present a constraint on capital: mobility between firms within the local labour market.

Workers regularly shifted work between factories and to other occupations in the locality in search of better wages and conditions, as exemplified by Daeng, an 18 year old woman, who had recently switched factories at the time of interview:

"The wages were better and it was more comfortable there. When there is no work to do they let you sit in the air-conditioned room. There are holidays, you can have time to rest, they let you out to eat on time" (interview 8 June 2014)

Workers used their mobility to access greater wages and benefits. This fact assumes greater significance in the context of the Lao industrial relations system. Independent trade unions are prohibited. The only union in the country is the state-controlled Lao Federation of Trade Unions (LFTU). The LFTU has a corporatist orientation which stresses tripartite negotiation to resolve issues (Fry 2012), with strikes effectively prohibited (GoL 2013). Workers' actions are thus constrained by this institutional landscape. Furthermore, LFTU units were not established at Savannakhet factories, with any problems putatively to be solved on an individualistic basis. The zone enacted no specific policies on labour, apart from one discussed below raised in response to issues of worker mobility. Here, it was not differential treatment of workers in the zone (Ong 2006) that was important but rather the broader state regulation concerning capital-labour relations in Laos. Regulation restrictive of labour and strikes was attractive to foreign investors, as suggested by several managers (13 January 2014; 27 February 2014). Mobility thus assumed even greater importance in this light and in the context of a tight labour market and expanding number of factories. As detailed below factories had to take measures to fix workers in place by providing increased wages and benefits and arguably more paternalistic and consensual labour regimes. Workers' mobility power (Smith 2006) was a key channel to derive greater benefits from the new foreign investment and represented a "material critique" of the social relations in factories (Mezzadra 2004, 270).

A third form of mobility was seasonal mobility between agriculture and industrial employment. Workers would stop working at factories temporarily or quit their jobs completely during the rice season. Workers were largely drawn from the mainly ethnically Lao rural and peri-urban hinterland of 
the zone and many remained embedded within subsistence-oriented rural production. Workers were typically the young daughters and sons of smallholder farming households, who owned plots of land of one or two hectares. These households grew an annual crop of rainfed rice and raised animals for household consumption and as a source of extra income. Household labour was then allocated to offfarm activities such as factory work. Workers stated that they continued to farm rice because then they would not have to buy rice and would therefore have the guarantee of subsistence. One worker highlighted this reasoning thus: "It is better to work in the fields because [at the factory] the wages are quite low so you can't buy rice with that money" (4 May 2014).

Fixity

I propose here that this latter type of mobility is constituted through a spatial practice of fixity. Workers and their families still deemed it necessary to control a small parcel of land and remain rooted in agricultural production. In turn, the ground was given for moving between two means of livelihood and pluralizing occupation. Hall (2012) notes that some Southeast Asian smallholders have actively sought to take advantage of opportunities to sell land and retreat from agriculture. While highlighting that fixity in agriculture is subject to dissolving, this point throws into relief the spatially strategic action that inheres in maintaining control over land, dialectically constituting the potential for mobility. The embeddedness of labour within an agrarian subsistence economy necessitated factories seeking a modus vivendi to stabilize production. Agriculture competed for industrial labour at times throughout the year, particularly the harvest season (factory manager 10 June 2014). A further problem was presented by workers being able to fall back on the subsistence safety net of household agricultural production, reducing the economic compulsion of dependence on wages and giving workers a means of resisting incorporation into industrial labour. A SEZA official is worth quoting at length on this point:

"they are used to freedom. When they shift to the factories they have to work in the team, they have to obey regulations including eating, drinking, dressing, working. Some people are not comfortable. Is Lao PDR different from other countries, like in other advanced countries? No job, no life, you cannot survive, but over here...if there is no work they still have rice...they still have fish ponds, they can go back to families, they still survive, much easier, very comfortable... why should they come for this pressure environment? Some people do believe like this...in other countries if you are unemployed it's a very big, big problem but over here it's normal" (20 December 2013) 
These issues were compounded by high levels of absenteeism, with absences capable of adding up to a "significant amount" of hours which imposed increased costs on factories (factory manager 18 March 2014).

\section{Capital's Response}

The contradictions of Lao workers' fixed and mobile class composition gave rise in turn to contradictory effects for capital. These effects resulted in key responses on the part of companies and the state in order to secure territorial coherence. The primary effects on territorial coherence were first that foreign capital was confronted with a restless, mobile workforce not fully dependent on wage labour for social reproduction, thus hindering recruitment and retention. Second, was that conversely, agriculture appeared to provide a subsidy to industrial production, allowing capital to escape some cost pressures of fully reproducing workers. Factories attempted to solve the conundrum of workers' mobility through regulation, offering increased wages and benefits, and recruiting from a wider area. The state enacted policies to reterritorialize migrants. The zone's territorial coherence required workers to be fixed in Lao territory and fixed within factories, as elaborated below. Struggle over workers' fixity and mobility thus became a key object of capital and state strategy.

First, zone factories, to prevent destabilizing competition for workers, together agreed on a regulation stipulating that workers who had left a zone factory were forbidden from working at another for six months (zone developer manager 13 January 2014). Second, factory managers reported increasing wages and benefits in order to keep workers from leaving. One non-zone factory manager, affected by the zone's demand for labour, described strategies for securing workers when significant numbers are moving elsewhere, "If we see they're leaving and leaving and leaving... We give them some extra bonuses" (18 March 2014). A zone factory manager reported problems with high turnover and because the company had invested in training workers it implemented measures to retain them:

"We try to give more incentives...New starters, before we gave them one month's probation without adjusting the wage, but now we adjust the wage for them after one month's probation. And after that we adjust the wages for them... and if they are sick they can get sick leave. Before we deducted their salary, their wages, but now we don't deduct. It's many things we have changed to do more incentives for them...to make them motivated and happy to stay working with us" (27 February 2014)

When asked how the workers had responded to this the manager claimed they were happy and "Even no one has left". Managers also claimed that the propensity of Lao workers to move influenced their labour control methods to take a more consensual and paternalist tack. If a harsher, more coercive approach was used workers had protested by simply leaving (zone developer manager 13 January 
2014; factory manager 18 March 2014). Workers appeared to confirm this when stating that they would simply leave if they experienced any problems with managers (workers 15 June 2014). Workers also evidenced signs of spontaneous, collective organization to take advantage of labour scarcity. Workers at one zone factory reported collectively asking for wage raises, which they received, at a time when other factories were opening up and increasing the competition for labour (workers 18 May 2014). The situation indicated nascent forms of class consciousness and collective action despite the political constraints. Factories using incentives to retain workers has been noted in the literature (Theobald 2002). The point here is to highlight the applicability of autonomist propositions about class composition causing adaptations on the part of capital, and furthermore to highlight how this composition is spatial and territorial. Third, according to managers from a local labour recruitment company contracting for three factories, the company had begun recruiting from ethnic minority villages in eastern Savannakhet province (23 and 24 May 2014). The class composition was thus also reworked through engaging distant worker mobilities and starting to change the more homogeneous ethnic Lao local workforce.

Territoriality of class composition was further emphasized by the state's efforts to reterritorialize labour in order to establish the new territorial coherence internal to the zone and between Laos and Thailand. Workers' command of space prompted state efforts to decompose labour's mobility power and the existing relations between distant Thai employment locations and home villages, by fixing workers as sedentary and re-bound in proximal community relations. The provincial Department of Labour reported efforts to work through village heads to dissuade villagers from migrating (Department of Labour official 9 January 2014). A SEZA official explained a reterritorialization strategy which stretched outside Laos's borders:

"we're going to work with the Lao embassies overseas, because people are going to work overseas, they need travel passports, travel documentation. So we also provide information to them. 'So in Laos we also have got business job offers, so why not you here [sic]?'... Of course I believe that if information is already provided to them, if they are, the benefits, the salaries comparison is not a very big difference, I don't think any Lao people are willing to work outside the country far away from their home town" (20 December 2013)

Finally, it must be noted that the modus vivendi achieved by the manufacturing companies with agricultural production was problematic but also advantageous, as it appeared to provide a subsidy which defrayed costs of labour's social reproduction. Rice growing was a central part of many workers' livelihoods. Rice provided food security and meant wages could be used for other needs. In 2014 a kilogram of rice cost around 3000 kip (US\$ 0.37). Rural Lao are estimated to consume around $200 \mathrm{~kg}$ 
of rice per capita annually (Eliste and Santos 2012). If this figure is taken as a guideline then it would cost 600,000 kip (US\$75) to keep a household member in rice for the year, a significant portion of one month's factory wages (in 2014 ranging between 900,000-1.2 million kip/US\$ 112-150). This could indicate a significant cash saving and would mean that rice growing was providing a subsidy for foreign-invested factories. Some workers considered the wages too low to give up growing rice. Without recourse to rice it is possible that factories would have faced increased calls to raise wages and benefits. Production for subsistence thus appeared to be re-oriented towards creating profits for the new investors, and the labour within the fields incorporated into global export production. The zone's form of territorial coherence with the surrounding agricultural hinterland thus calls into question any tidy narrative of linear structural transformation (Sanyal 2007) in Laos, suggesting instead a far more spatially and economically complex "interpenetration" of agrarian and industrial, production and reproduction spaces (Rigg 2001) which raises doubts about the long-term viability of this form of industrial development.

\section{Conclusion}

To summarize, special economic zones can be understood as a form of territorial organization which seek to attain coherence for capital accumulation. Territorial coherence operates at multiple scales including within the zone, across spheres of production and social reproduction inside and outside of the zone, and between national jurisdictions. The zone as territorial construct creates forms of coherence across borders that are highly uneven and exclusionary, privileging the relations between far-flung locations, while attempting to disengage from local contexts on which it nevertheless depends. Territorial organization can be understood as both force and relation of production and the latter can be fruitfully interpreted using class composition. The notion of class composition can then be spatialized in terms of workers' fixity and mobility. The relations of production needed to attain territorial coherence for accumulation then become the object of struggles that saturate the overlapping, multiscalar spaces of the zone.

Analyzing special economic zones from the perspective of territorial coherence offers several advantages. Reading the relations of production in terms of a spatial class composition - and the contestation implied - allows us to integrate workers' agency into the analysis of "experimental" forms of territory. The focus on territorial class composition also has the related benefit of providing a frame which elevates workers' social reproduction as an intrinsic part of the analysis and evokes a correspondingly wider scope of causality and effect for investigation. This leads to a third benefit, that territorial coherence provides a potential pathway for understanding how SEZs' construction and effects are implicated in the "stretching and remixing of different scales of accumulation" (Mezzadra 
and Neilson 2013, 214). Attention to territorial coherence makes visible the interlinked ways zones hang together internally, with their surrounding territory, and also their global and regional bridging effects. The suggestion here is not the easy conclusion that the global economy and its relations of production are constituted locally. Instead it is to say that there is a more complex layering of scales and spaces in which fragility inheres and which provokes consistent wilful action on the part of differently situated actors to create and maintain the formation. Territory - and the special economic zone - is semi-fixed, and actors to whom it provides benefits struggle to hold its shape which is at risk of blurring, as mobility both defines and undermines it. The way is thus opened for analyses which disrupt the "race to the bottom" pessimism of some SEZ analysis and imply the possibility of subaltern agency to influence capitalist development, illustrated for instance by the way mobility power fed into collective demands at one factory.

The territorial construct of the Savannakhet border enclave could only gain coherence for accumulation by coming to terms with the wider territorial organization of workers' social reproduction characterized by the migration/agriculture axis. It was here at the interface of an existing class composition and the emerging one brought by increasing industrialization that economic development and the division of spoils took place. The spatial practices of labour both problematized accumulation in the zone and provided a basis for capital accumulation. With low wages an important motivation for factories' relocation, the zone was sustained by sourcing labour from an agrarian hinterland which absorbed some of the costs of workers' reproduction, even as an agrarian base was a factor in leveraging higher wages than capital had expected to pay. The latter appeared tolerable for capital in light of the benefits from tax, border location, and incomplete agrarian transition. The form of regionalization being enacted in Laos thus appears as constituted by contestation over capital's production space and workers' social reproduction space. Further wages rises could also threaten this fragile, territorial compact, as could the development of a proposed SEZ across the border in Thailand competing for scarce, mobile labour (Bangkok Post 2017). Workers' spatial practices will it seems remain a key part of ongoing restructurings of Southeast Asian regional space.

\section{Acknowledgements}

The author thanks Adam Hanieh, Dennis Arnold, Frido Wenten and four anonymous reviewers for their comments on previous versions.

\section{Endnotes}

\footnotetext{
${ }^{1}$ See Soja (1989).
} 


\footnotetext{
${ }^{2}$ The ASEAN Economic Community is also a current framework for integration, although not of primary relevance here as it started in 2015, after the fieldwork period.

${ }^{3}$ This figure refers to registered capital, i.e. actually existing assets in Laos at the initial phase of investment. This is opposed to approved capital, which the statistics record but may not reflect actually implemented projects, and full invested figures are not available.

${ }^{4}$ All names of companies and workers have been changed.
} 


\section{References}

ADB (2016) The Role of Special Economic Zones in Improving Effectiveness of GMS Economic Corridors. Manila: Asian Development Bank.

Agbiboa D (2012) Offsetting the development costs? Brain drain and the role of training and remittances. Third World Quarterly 33(9):1669-1683.

Alberti G (2014) Mobility strategies, 'mobility differentials' and 'transnational exit': The experiences of precarious migrants in London's hospitality jobs. Work, Employment and Society 28(6):865-881.

Allen J (2011) Topological twists: Power's shifting geographies. Dialogues in Human Geography $1(3): 283-298$.

Amin A (2002) Spatialities of globalisation. Environment and Planning A 34(3):385-399.

Appel H (2012) Walls and white elephants: Oil extraction, responsibility, and infrastructural violence in Equatorial Guinea. Ethnography 13(4):439-465.

Arnold D (2012) Spatial practices and border SEZs in Mekong Southeast Asia. Geography Compass 6(12):740-751.

Arnold D and Pickles J (2011) Global work, surplus labor, and the precarious economies of the border. Antipode 43(5):1598-1624.

Bach J (2011) Modernity and the urban imagination in economic zones. Theory, Culture and Society. 28(5):98-122.

Bair J and Werner M (2011) Commodity chains and the uneven geographies of global capitalism: a disarticulations perspective. Environment and Planning A 43(5):988-997.

Baird I (2011) Turning land into capital, turning people into labour: Primitive accumulation and the arrival of large-scale economic land concessions in the Lao People's Democratic Republic. New Proposals: Journal of Marxism and Interdisciplinary Inquiry 5(1):10-26.

Baird I, Shoemaker B and Manorom K (2015) The people and their river, the World Bank and its dam: Revisiting the Xe Bang Fai river in Laos. Development and Change 46(5):1080-1105.

Bangkok Post (2017) Mukdahan makes its mark. 13 March

Berndt $C$ and Boeckler M (2011) Performative regional (dis)integration: Transnational markets, mobile commodities, and bordered North-South differences. Environment and Planning $A$ 43(5):1057-1078.

Caraway T (2005) The political economy of feminization: From "cheap labour" to gendered discourses of work. Politics and Gender 1(3):399-429.

Carmichael L and Herod A (2012) Dockers and seafarers: What the politics of spatial embeddedness and geographical scale have meant for union organizing in the European maritime trades. Labor Studies Journal 37(2):203-227. 
Cleaver H (1992) The inversion of class perspective in Marxian theory: From valorisation to selfvalorisation. In W Bonefeld, R Gunn and K Psychopedis (eds) Open Marxism Volume II: Theory and Practice (pp. 106-144). London: Pluto.

Coe $\mathrm{N}$ and Jordhus-Lier D (2011) Constrained agency? Re-evaluating the geographies of labour. Progress in Human Geography 35(2):211-233.

Cox K (2013) Territory, scale and why capitalism matters. Territory, Politics, Governance 1(1):46-61.

Cross J (2010) Neoliberalism as unexceptional: Economic zones and the everyday precariousness of working life in South India. Critique of Anthropology 30(4):355-373.

Cumbers A, Helms G and Swanson K (2010) Class, agency and resistance in the old industrial city. Antipode 42(1):46-73.

Cumbers A, Nativel C and Routledge P (2008) Labour agency and union positionalities in global production networks. Journal of Economic Geography 8(3):369-387.

Doucette J and Lee S-O (2015) Experimental territoriality: Assembling the Kaesong industrial complex in North Korea. Political Geography 47:53-63.

Dunn B (2004) Capital mobility and the embeddedness of labour. Global Society 18(2):127-143.

Dyer-Witheford N (2004) Autonomist Marxism and the Information Society. s.l.: Treason Press.

Eliste P and Santos N (2012) Lao People's Democratic Republic Rice Policy Study 2012. Rome: FAO.

Faludi A (2013) Territorial cohesion, territorialism, territoriality and soft planning: A critical review. Environment and Planning A 45(6):1302-1317.

Fau N, Khonthapane S and Taillard C (eds) (2014) Transnational Dynamics in Southeast Asia: The Greater Mekong Subregion and Malacca Straits Economic Corridors. Singapore: ISEAS.

Fry S (2012) The Lao Federation of Trade Unions: A classic dualist union. International Journal of Employment Studies 20(2):32-54.

Glassman J (2007) Recovering from crisis: The case of Thailand's spatial fix. Economic Geography 83(4):349-370.

Glassman J (2010) Bounding the Mekong: The Asian Development Bank, China, and Thailand. Honolulu: University of Hawai'i Press.

GoL (2003) Decree of the Prime Minister on the Management Regulations and Incentive Policies Regarding the Savan-Seno Special Economic Zone, No. 177. Vientiane: Prime Minister's Office GoL (2012) Development Strategy for Special and Specific Economic Zone (SEZ) in the Lao PDR, 20112020. Vientiane: S-NCSEZ.

GoL (2013) Labor Law. Vientiane: National Assembly. 
GoL (2014) Statistical Yearbook 2013. Vientiane: Ministry of Planning and Investment/Lao Statistics Bureau.

GoL (2016) Where to Invest: Special Economic Zone (SEZ). Available at: http://www.investlaos.gov.la/index.php/where-to-invest/special-economic-zone. Accessed: 6 November 2017.

Gunawardana S (2016) 'To finish, we must finish': everyday practices of depletion in Sri Lankan export-processing zones. Globalizations 13(6):861-875.

Hall D (2012) Rethinking primitive accumulation: Theoretical tensions and rural Southeast Asian complexities. Antipode 44(4):1188-1208.

Harvey D (2006) [1982]. The Limits to Capital. London: Verso.

Hudson R (2007) Regions and regional uneven development forever? Some reflective comments on theory and practice. Regional Studies 41(9):1149-1160.

Ince A, Featherstone D, Cumbers A, MacKinnon D and Strauss K (2015) British jobs for British workers? Negotiating work, nation, and globalisation through the Lindsey Oil Refinery disputes. Antipode 47(1):139-157.

Jones M (2009) Phase space: Geography, relational thinking, and beyond. Progress in Human Geography 33(4):487-506.

Kelly P (2009) From global production networks to global reproduction networks: Households, migration, and regional development in Cavite, the Philippines. Regional Studies 43(3):449-461.

Kelly P (2013) Production networks, place and development: Thinking through global production networks in Cavite, Philippines. Geoforum 44:82-92.

Khumya T and Kusakabe K (2015) Road development, and changes in livelihood and mobility in Savannakhet, Lao PDR. Development in Practice 25(7):1011-1024.

Laungaramsri P (2014) Commodifying sovereignty: Special economic zones and the neoliberalization of the Lao frontier. Journal of Lao Studies 5(1):29-56.

Lestrelin G, Castella J-C and Bourgoin J (2012) Territorialising sustainable development: The politics of land-use planning in Laos. Journal of Contemporary Asia 42(4):581-602.

Levien M (2012) The land question: Special economic zones and the political economy of dispossession in India. Journal of Peasant Studies 39(3-4):933-969.

Manivong V, Cramb R and Newby J (2014) Rice and remittances: Crop intensification versus labour migration in Southern Laos. Human Ecology 42(3):367-379.

Mercer C (2017) Landscapes of extended ruralisation: Postcolonial suburbs in Dar es Salaam, Tanzania. Transactions of the Institute of British Geographers 42(1):72-83.

Mezzadra S (2004) The right to escape. Ephemera: Theory and Politics in Organization 4(3):267-275. 
Mezzadra S and Neilson B (2013) Border as Method, Or, the Multiplication of Labor. Durham; London: Duke University Press.

Neveling P (2015) Export processing zones, special economic zones and the long march of capitalist development policies during the Cold War. In L James and E Leake (eds) Decolonization and the Cold War: Negotiating Independence (pp.63-84). London; New York: Bloomsbury Academic.

Nolintha V (2011) Cities, SEZs and connectivity in major provinces of Laos. In M Ishida (ed) Intra- and Inter-City Connectivity in the Mekong Region: BRC Research Report No.6 (pp.175-240). Bangkok: IDEJETRO.

Nyiri P (2012) Enclaves of improvement: Sovereignty and developmentalism in the special zones of the China-Lao borderlands. Comparative Studies in Society and History 54(3):533-562.

Ollman B (2003) Dance of the Dialectic: Steps in Marx's Method. Urbana: University of Illinois Press

Ong A (2006) Neoliberalism as Exception: Mutations in Citizenship and Sovereignty. Durham; London: Duke University Press.

Oraboune S (2011) Lao PDR's industrial development policy and intermediate goods trade. In M Kagami (ed) Intermediate Goods Trade in East Asia: Economic Deepening Through FTAs/EPA (pp. 266-296). Bangkok Research Centre Report No. 5. Bangkok: IDE-JETRO.

Painter J (2010) Rethinking territory. Antipode 42(5):1090-1118.

Pearson R and Kusakabe K (2012) Who cares? Gender, reproduction, and care chains of Burmese migrant workers in Thailand. Feminist Economics 18(2):149-175.

Pun N and Smith C (2007) Putting transnational labour process in its place: The dormitory labour regime in post-socialist China. Work, Employment and Society 21(1):27-45

Raffestin C (2012) Space, territory and territoriality. Environment and Planning D: Society and Space 30(1):121-141.

Rigg J (2001) More than the Soil: Rural Change in Southeast Asia. Harlow: Prentice Hall.

Sanyal K (2007) Rethinking Capitalist Development: Primitive Accumulation, Governmentality and Post-colonial Capitalism. New Delhi; London: Routledge.

Smith C (2006) The double indeterminacy of labour power: Labour effort and labour mobility. Work, Employment and Society 20(2):389-402.

Soja E (1989) Postmodern Geographies: The Reassertion of Space in Critical Social Theory. London: Verso.

SPA (2013) Aggregated Lao Labour Working Abroad. Unpublished data.

SPA (2014) Foreign Investment Projects in Savannakhet Province, 1992-2014. Unpublished data.

Swyngedouw E (1992) Territorial organization and the space/technology nexus. Transactions of the Institute of British Geographers 17(4):417-433. 
Tan D (2012) "Small is beautiful": Lessons from Laos for the study of Chinese overseas. Journal of Current Chinese Affairs 41(2):61-94.

Theobald S (2002) Working for global factories: Thai women in electronics export companies in the Northern Regional Industrial Estate. In D-SS Gills and N Piper (eds) Women and Work in Globalising Asia (pp. 131-153). London: Routledge.

Vientiane Times (2011) Industrial park opens for business in Savannakhet. 22 November 